\title{
Modelling, Simulation and Geometric Optimization of Cross Flow Recuperative Heat Exchanger Based on Controllability Condition Number
}

DALIBOR Z. STEVIĆ, University of Belgrade,

Faculty of Mechanical Engineering, Belgrade DRAGUTIN LJ. DEBELJKOVIĆ, University of Belgrade, Faculty of Mechanical Engineering, Belgrade GORAN V. SIMEUNOVIĆ, University of Belgrade,

Faculty of Mechanical Engineering, Innovation Centre, Belgrade
Original scientific paper

UDC: 536.24

DOI: 10.5937/tehnika1702221S

This paper presents the algebraic mathematical model of cross - flow heat exchanger derived on the basis of transport approach. Theirs operation in the face of variable loads is usually controlled by manipulating inlet fluid temperatures or mass flow rates, where the controlled variable is usually the output temperature of principal flow. The aim of this paper is to optimize the geometry of a tube with the inlet flow of principal incompressible fluid and an external cross - country flow of compressible fluid, based on performance index expressed throughout its controllability characteristics. Thus the condition number has been used to provide the necessary information on the best situation for control of the exchanger under consideration. This concept can also provide us with information about the easiest operating condition to control a particular output. A transient model of a cross-flow heat exchanger is developed, where an implicit formulation is used for transient numerical solutions. The condition number performed throughout the ratio of geometric parameters of tube is optimized, subject to volume constraints, based on the optimum operation in terms of output controllability.

The reported optimized aspect ratio, water mass flow rate and output controllability are studied for different external properties of the tube.

Key words: Cross - flow heat exchanger, transport method, controllability condition number

\section{INTRODUCTION}

The heat exchangers are designed to achieve certain requirements in the steady state which implies that transient response of heat exchanger must be known to define correct control strategy.

The mathematical model of the heat exchanger must be known in order to determine the transient response.

Large number of researchers was working on this problem within last decade such as [01, 02].

In this paper, the recuperative cross-flow heat exchanger is observed, shown in Fig.1, as a process with distributed parameters.

Among the many kinds of water-to-air heat excha-

Author's address: Dalibor Stević, University of Belgrade, Faculty of Mechanical Engineering, Belgrade, Kraljice Marije 16, e-mail: dbstevic@yahoo.com

Paper received: 11.01.2017.

Paper accepted: 14.02.2017. ngers, the cross-flow geometry is very common.

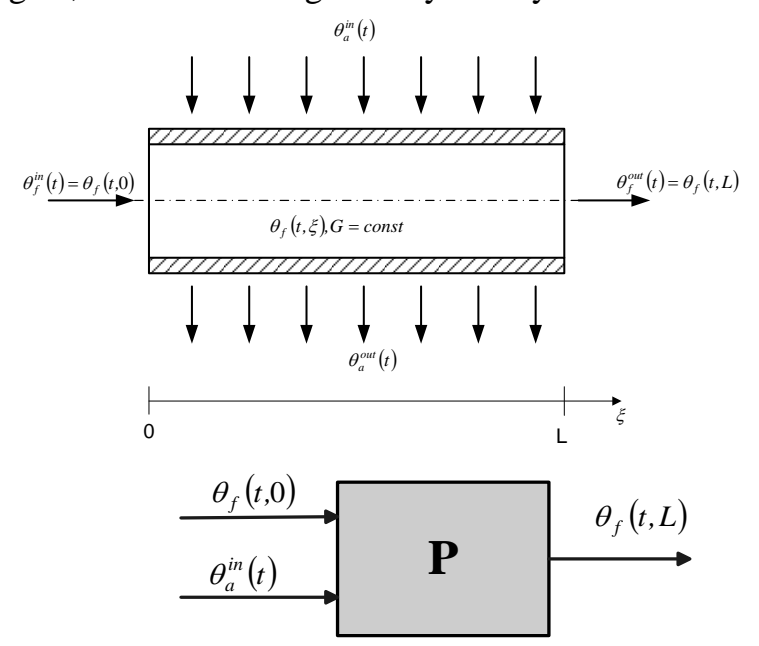

Figure 1 - Cross-flow heat exchanger

The geometry of cross-flow heat exchangers can be complicated, but in this paper we observe the case with the simplest geometry that can be easily computed. This heat exchanger consists of a single tube 
with fluid (water) flow inside and cross flow of hot air outside.

The mathematical model of the cross flow heat exchanger, shown in Fig. 1, is carried out on the basis of the classical assumptions, cited in [03].

\section{THE TRANSPORT APPROACH}

The transport approach represents the special method for mathematical modelling of heat exchangers [04]. This approach is based on dividing observed heat exchanger into the same $p$ cells.

The fundamental low of energy conservation is derived by means of the finite differences for every cell with respect to finite time interval $\Delta t$. In this manner the system of partial differential equations is transformed to the system of algebraic equations which are easy to solve by numeric, iterative methods.

Lets observe the $k$-th cell, $k=1,2, \ldots, p$, of the crossflow heat exchanger.

Considering heat balance within observed cell, it can be identified the heat input and output by fluid flow through boundary of the cell and heat exchange between the fluid in the cell and the wall.

Considering the changes of the specific physical values in the certain time interval defined with $t$ and $t+\Delta t$.

The amount of heat exchange into the $k$-th cell for the time interval $\Delta t$ can be written in the following form:

$$
\begin{gathered}
\bar{Q}(\Delta t)=\frac{Q(t)+Q(t+\Delta t)}{2} \Delta t \\
\bar{Q}_{\text {in }}(\Delta t)=\frac{Q_{\text {in }}(t)+Q_{\text {in }}(t+\Delta t)}{2} \Delta t \\
\bar{Q}_{\text {out }}(\Delta t)=\frac{Q_{\text {out }}(t)+Q_{\text {out }}(t+\Delta t)}{2} \Delta t \\
\bar{Q}_{w f}(\Delta t)=\frac{Q_{w f}(t)+Q_{w f}(t+\Delta t)}{2} \Delta t,
\end{gathered}
$$

where $\bar{Q}_{i n}(\Delta t)$ is the heat change at the cell inlet for the time interval $\Delta t, \bar{Q}_{\text {out }}(\Delta t)$ is the heat change at cell outlet and $\bar{Q}_{w f}(\Delta t)$ the heat exchange between the wall and the fluid in the cell.

The heat flow can be presented as:

$$
\begin{aligned}
& Q_{i n}(t)=c_{f} G_{f} \theta_{f}^{\text {in }}(t), Q_{\text {out }}(t)=c_{f} G_{f} \theta_{f}^{\text {out }}(t), \\
& Q_{w f}(t)=\alpha_{w f} A_{w f}\left(\theta_{w}(t)-\theta_{f}(t)\right) .
\end{aligned}
$$

Assuming that fluid temperature in the cell can be expressed in the following form:

$$
\theta_{f}^{\text {ave }}(t)=\frac{\theta_{f}^{\text {in }}(t)+\theta_{f}^{\text {out }}(t)}{2}
$$

The heat content in the fluid for the observed cell can be expressed in the following form:

$$
\bar{Q}(t)=m_{f} c_{f} \theta_{f s r}(t)=m_{f} c_{f} \frac{\theta_{f}^{\text {in }}(t)+\theta_{f}^{\text {out }}(t)}{2}
$$

The total amount of heat accumulated in the observed cell for the time interval $((t+\Delta t)-t)=\Delta t$ can be written as follows:

$$
\begin{aligned}
\Delta \bar{Q}(\Delta t) & =\bar{Q}(t+\Delta t)-\bar{Q}(t) \\
& =\bar{Q}_{\text {in }}(\Delta t)-\bar{Q}_{\text {out }}(\Delta t)+\bar{Q}_{w f}(\Delta t)
\end{aligned}
$$

where:

$$
\begin{gathered}
\bar{Q}_{\text {in }}(\Delta t)=c_{f} G_{f} \frac{\theta_{f}^{\text {in }}(t)+\theta_{f}^{\text {in }}(t+\Delta t)}{2} \Delta t \\
\bar{Q}_{\text {out }}(\Delta t)=c_{f} G_{f} \frac{\theta_{f}^{\text {out }}(t)+\theta_{f}^{\text {out }}(t+\Delta t)}{2} \Delta t \\
\bar{Q}_{w f}(\Delta t)=\frac{\alpha_{w f} A_{w f} \Delta t}{2}\left(\theta_{w}(t)-\frac{\theta_{f}^{\text {in }}(t)+\theta_{f}^{\text {out }}(t)}{2}\right)+ \\
+\frac{\alpha_{w f} A_{w f} \Delta t}{2}\left(\theta_{w}(t+\Delta t)-\frac{\theta_{f}^{\text {in }}(t+\Delta t)+\theta_{f}^{\text {out }}(t+\Delta t)}{2}\right)
\end{gathered}
$$

The balance equation for the observed cell is obtained in the following form:

For the fluid in the tube:

$$
\begin{aligned}
m_{f} c_{f} & \theta_{f, k}^{\text {ave }}(t+\Delta t)-m_{f} c_{f} \theta_{f, k}^{\text {ave }}(t) \\
& =\frac{c_{f} G_{f} \Delta t}{2}\left(\theta_{f, k}^{\text {in }}(t)-\theta_{f, k}^{\text {in }}(t+\Delta t)\right) \\
& -\frac{c_{f} G_{f} \Delta t}{2}\left(\theta_{f, k}^{\text {out }}(t)-\theta_{f, k}^{\text {out }}(t+\Delta t)\right) \\
& +\frac{\alpha_{w f} A_{w f} \Delta t}{2}\left(\theta_{w, k}(t)-\frac{\theta_{f, k}^{i n}(t)+\theta_{f, k}^{\text {out }}(t)}{2}\right) \\
& +\frac{\alpha_{w f} A_{w f} \Delta t}{2}\left(\theta_{w, k}(t+\Delta t)-\frac{\theta_{f, k}^{i n}(t+\Delta t)+\theta_{f, k}^{\text {out }}(t+\Delta t)}{2}\right)_{(8)}
\end{aligned}
$$

For the wall:

$$
\begin{aligned}
& m_{w} c_{w}\left(\theta_{w, k}(t+\Delta t)-\theta_{w, k}(t)\right)= \\
& =\frac{\alpha_{a w} A_{a w} \Delta t}{2}\left(\theta_{a}(t)-\theta_{w, k}(t)\right)+ \\
& +\frac{\alpha_{a w} A_{a w} \Delta t}{2}\left(\theta_{a}(t+\Delta t)-\theta_{w, k}(t+\Delta t)\right)- \\
& -\frac{\alpha_{w f} A_{w f} \Delta t}{2}\left(\theta_{w, k}(t)-\frac{\theta_{f, k}^{i n}(t)+\theta_{f, k}^{\text {out }}(t)}{2}\right)- \\
& -\frac{\alpha_{w f} A_{w f} \Delta t}{2}\left(\theta_{w, k}(t+\Delta t)-\frac{\theta_{f, k}^{\text {in }}(t+\Delta t)+\theta_{f, k}^{\text {out }}(t+\Delta t)}{2}\right)
\end{aligned}
$$


For the air:

$$
G_{a} c_{a}\left(\theta_{a}^{\text {in }}(t)-\theta_{a}^{\text {out }}(t)\right)=\alpha_{a w} A_{a w}\left(\theta_{a}(t)-\theta_{w, k}(t)\right)
$$

The mathematical model for the observed cell after some simple mathematical transformation can be obtained in the following form:

$$
\begin{aligned}
\theta_{f, k}^{\text {out }}(t+\Delta t)= & a_{1} \theta_{f, k}^{\text {out }}(t)+a_{2} \theta_{f, k}^{\text {in }}(t) \\
& +a_{3} \theta_{w, k}(t)+a_{4} \theta_{f, k}^{\text {in }}(t+\Delta t)+a_{3} \theta_{w, k}(t+\Delta t) \\
\theta_{w, k}(t+\Delta t)= & b_{1} \theta_{w, k}(t)+b_{2} \theta_{a}^{\text {in }}(t) \\
& +b_{2} \theta_{a}^{\text {in }}(t+\Delta t)+b_{3} \theta_{f, k}^{\text {in }}(t)+b_{3} \theta_{f, k}^{\text {in }}(t+\Delta t) \\
& +b_{3} \theta_{f, k}^{\text {out }}(t)+b_{3} \theta_{f, k}^{\text {out }}(t+\Delta t)
\end{aligned}
$$

Eliminating $\theta_{w, k}(t+\Delta t)$ from Eq. (11) and (12) the outlet temperature from the $k$-th cell can be expressed in the following form:

$$
\begin{aligned}
\theta_{f, k}^{\text {out }}(t+\Delta t)= & c_{1} \theta_{f, k}^{\text {out }}(t)+c_{2} \theta_{f, k}^{\text {in }}(t)+c_{3} \theta_{w, k}(t) \\
& +c_{4} \theta_{a}^{\text {in }}(t)+c_{5} \theta_{f, k}^{\text {in }}(t+\Delta t)+c_{4} \theta_{a}^{\text {in }}(t+\Delta t)
\end{aligned}
$$

where:

$$
\begin{gathered}
c_{1}=\frac{a_{1}+a_{3} b_{3}}{1-a_{3} b_{3}}, \quad c_{2}=\frac{a_{2}+a_{3} b_{3}}{1-a_{3} b_{3}}, \quad c_{3}=\frac{a_{3}+a_{3} b_{1}}{1-a_{3} b_{3}} \\
c_{4}=\frac{a_{3} b_{2}}{1-a_{3} b_{3}}, \quad c_{5}=\frac{a_{4}+a_{3} b_{3}}{1-a_{3} b_{3}}
\end{gathered}
$$

and:

$$
\begin{gathered}
a_{1}=\frac{2 m_{f} c_{f}-2 c_{f} G_{f} \Delta t-\alpha_{z f} A_{z f} \Delta t}{2 m_{f} c_{f}+2 c_{f} G_{f} \Delta t+\alpha_{z f} A_{z f} \Delta t} \\
a_{2}=\frac{2 m_{f} c_{f}+2 c_{f} G_{f} \Delta t-\alpha_{z f} A_{z f} \Delta t}{2 m_{f} c_{f}+2 c_{f} G_{f} \Delta t+\alpha_{z f} A_{z f} \Delta t} \\
a_{3}=\frac{2 \alpha_{z f} A_{z f} \Delta t}{2 m_{f} c_{f}+2 c_{f} G_{f} \Delta t+\alpha_{z f} A_{z f} \Delta t} \\
a_{4}=\frac{2 c_{f} G_{f} \Delta t-2 m_{f} c_{f}-\alpha_{z f} A_{z f} \Delta t}{2 m_{f} c_{f}+2 c_{f} G_{f} \Delta t+\alpha_{z f} A_{z f} \Delta t} \\
b_{1}=\frac{\left(2 m_{z} c_{z}-\alpha_{g z} A_{g z} \Delta t-\alpha_{z f} A_{z f} \Delta t\right)\left(2 G_{g} c_{g}+\alpha_{g z} A_{g z}\right)+\alpha_{g z}^{2} A_{g z}^{2} \Delta t}{\left(2 m_{z} c_{z}+\alpha_{g z} A_{g z} \Delta t+\alpha_{z f} A_{z f} \Delta t\right)\left(2 G_{g} c_{g}+\alpha_{g z} A_{g z}\right)-\alpha_{g z}^{2} A_{g z}^{2} \Delta t} \\
b_{2}=\frac{2 \alpha_{g z} A_{g z} \Delta t G_{g} c_{g}}{\left(2 m_{z} c_{z}+\alpha_{g z} A_{g z} \Delta t+\alpha_{z f} A_{z f} \Delta t\right)\left(2 G_{g} c_{g}+\alpha_{g z} A_{g z}\right)-\alpha_{g z}^{2} A_{g z}^{2} \Delta t} \\
b_{3}=\frac{\alpha_{z f} A_{z f} \Delta t\left(2 G_{g} c_{g}+\alpha_{g z} A_{g z}\right)}{2\left(2 m_{z} c_{z}+\alpha_{g z} A_{g z} \Delta t+\alpha_{z f} A_{z f} \Delta t\right)\left(2 G_{g} c_{g}+\alpha_{g z} A_{g z}\right)-2 \alpha_{g z}^{2} A_{g z}^{2} \Delta t}
\end{gathered}
$$

Equation (13) is used for the simulation of process in cross-flow heat exchanger.

Assuming, in the first step, $\theta_{f, k}^{i n}(t+\Delta t)=\theta_{f, k}^{i n}(t)$ and $\theta_{a}^{i n}(t+\Delta t)=\theta_{a}^{i n}(t)$ where $\Delta t$ is small enough, the outlet temperature is determinate for the $k$-th cell, $k=1,2, \ldots, p$.

Repeating this procedure for different values of $\Delta t$ the fluid temperature of cross-flow heat exchanger at the cells outlet is obtained as a function of time.

Simulation results are placed on Figure 2 - Figure 7 , showing changes in temperature of the fluid at the outlet of the heat exchanger and the temperature changes in the outputs from the individual cells of the heat exchanger with respect to the changes of the input temperature of the fluid or changes in the input gases temperature.

In the present case, it is assumed that the heat exchanger consists of five cells.

First we consider the case when there is a change of the input temperature of the fluid from the initial value $110\left[{ }^{0} C\right]$ to a new value $120\left[{ }^{0} C\right]$, under a constant temperature of the inlet gas, and then the case when the incoming temperature gas $220\left[{ }^{0} \mathrm{C}\right]$ change to a new, certain, value $240\left[{ }^{0} C\right]$ during a constant inlet temperature of the fluid.

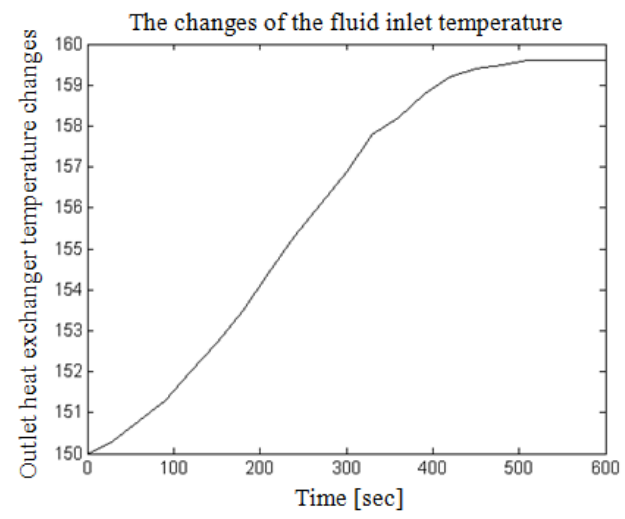

Figure 2 - Outlet heat exchanger temperature changes with respect to the changes of the fluid inlet temperature

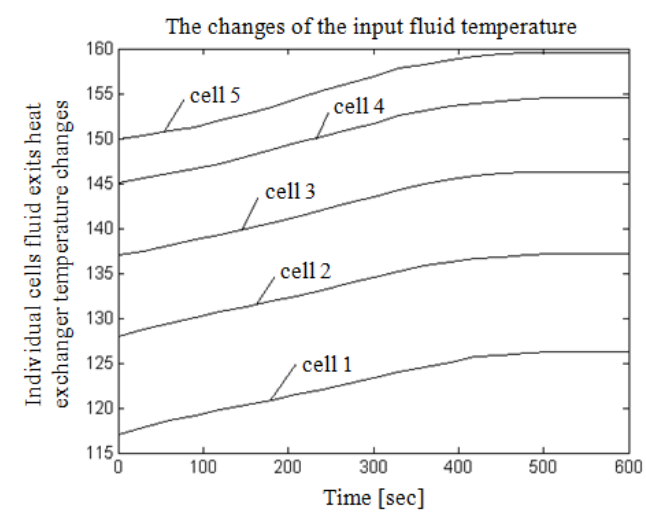

Figure 3 - Individual cells fluid outlet heat exchanger temperature changes with respect to the changes of the input fluid temperature 


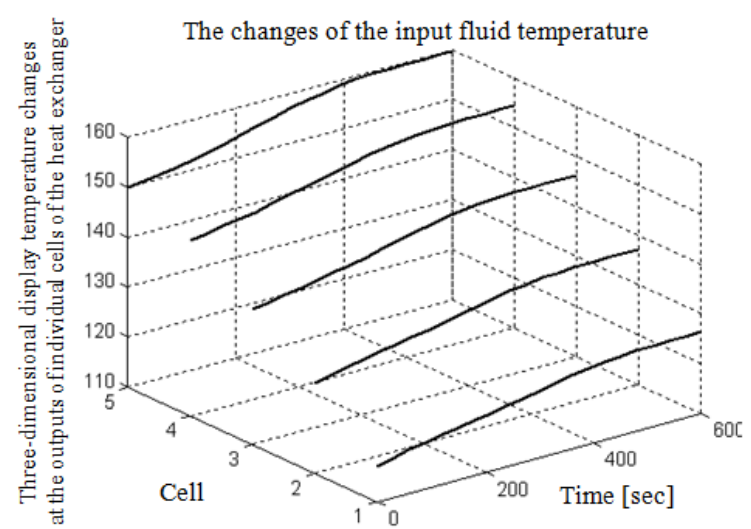

Figure 4 - Three-dimensional display temperature changes at the outputs of individual cells of the heat exchanger with respect to the change of the input fluid temperature

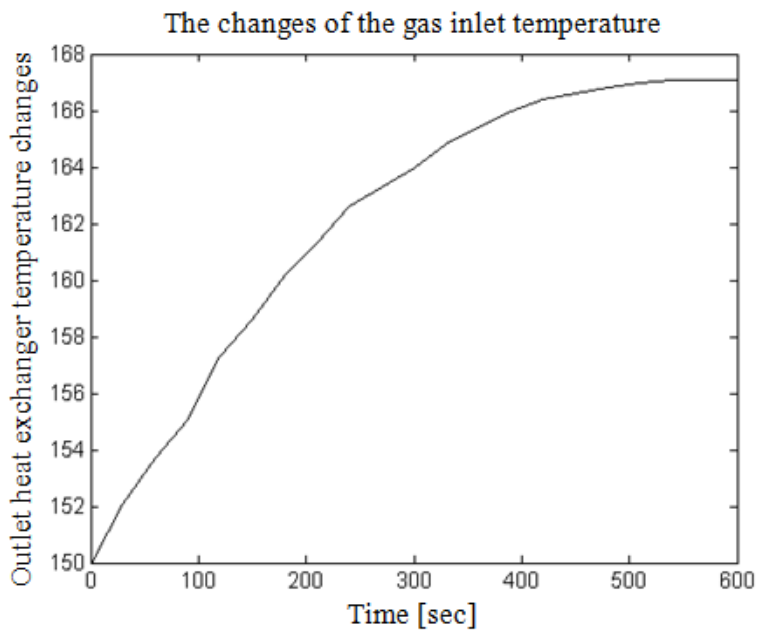

Figure 5 - Outlet heat exchanger temperature changes with respect to the changes of the gas inlet temperature

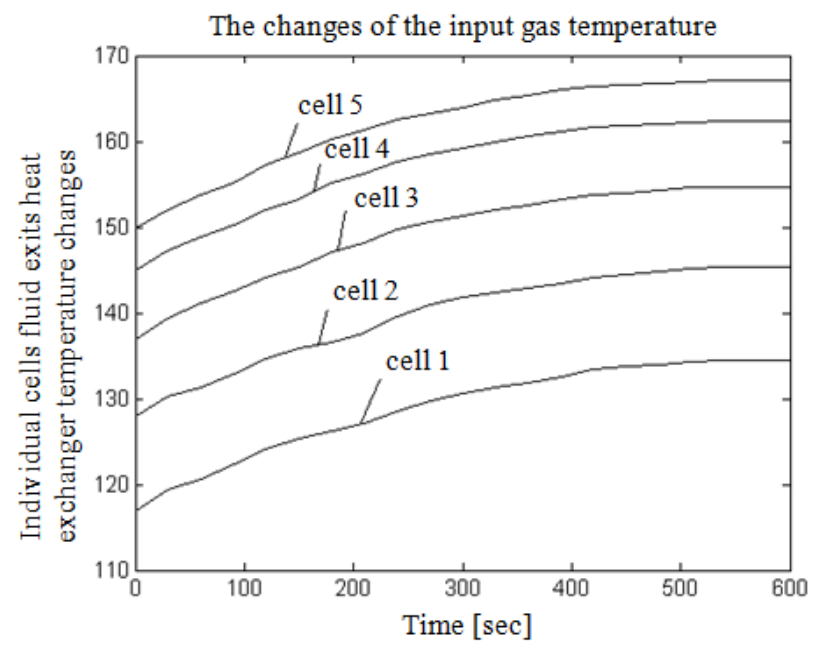

Figure 6 - Individual cells fluid outlet heat exchanger temperature changes with respect to the changes of the input gas temperature

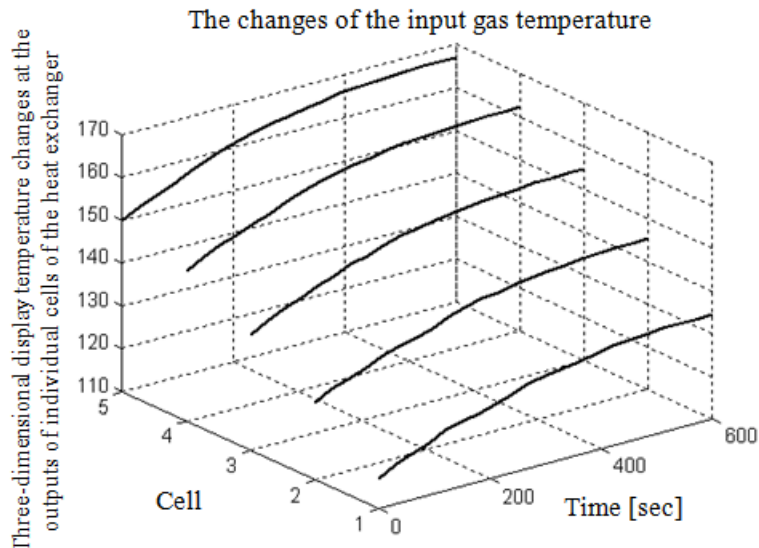

Figure 7 - Three-dimensional display temperature changes at the outputs of individual cells of the heat exchanger with respect to the change of the input gas temperature

\section{GEOMETRIC OPTIMIZATION}

The configuration of thermal processes is usually designed based on its steady-state performance subject to global and local constraints, where its configuration is optimized for maximization of global performance or for minimization of total cost .

This is usually done by assuming the process configuration and then simulating its operation under various conditions to determine its best operating conditions.

Recently, another approach has been used which consists in searching for the best design parameter to determine the optimal geometry that would produce the maximum performance.

In this procedure the configuration of the system is simulated and the effect of the system geometric parameters on its performance is analyzing to determine the optimal geometry for this process.

The maximum performance is usually determined by the maximum output of the system.

The optimal geometry of the heat exchanger is searching in order to achive the best controllability of the observed system.

Therefore, the process controllability, the ability of a process to be control by the available control input in the form of a inlet temperatures, is the criterion used for optimization.

This can be done by investigating its state controllability and output controllability with the system geometry for a better system design.

The configuration of cross-flow heat exchanger is optimized in this work to produce the best geometry in terms of the process controllability.

The air inlet temperature and the fluid inlet temperature are used as control inputs. 
The problem of geometric optimization in this paper is analyzed for the mathematical model of the same cross-flow heat exchanger derived using the method of physical dicretization [05], which leads to the analogous transient respones for all cells, as well, as for the whole heat exchanger.

For the sake of breavity, this model is, presented here only, while the complete modelling process can be found in [03].

We consider the case, when number of cells equal 5 (five).

$$
\begin{gathered}
\dot{\mathbf{x}}(t)=A \mathbf{x}(t)+B \mathbf{u}(t) \\
x_{i}(t)=\mathbf{c}^{T} \mathbf{x}(t)
\end{gathered}
$$

where:

$$
\begin{aligned}
& \mathbf{x}(t)==\left[\begin{array}{l}
\mathbf{x}_{1}(t) \\
\mathbf{x}_{2}(t) \\
\mathbf{x}_{3}(t) \\
\mathbf{x}_{4}(t) \\
\mathbf{x}_{5}(t)
\end{array}\right]=\left[\begin{array}{l}
\overline{\Delta \theta}_{f 1}(t) \\
\overline{\Delta \theta}_{z 1}(t) \\
\overline{\Delta \theta}_{f 2}(t) \\
\overline{\Delta \theta}_{z 2}(t) \\
\overline{\Delta \theta}_{f 3}(t) \\
\overline{\Delta \theta}_{z 3}(t) \\
\overline{\Delta \theta}_{f 4}(t) \\
\overline{\Delta \theta}_{z 4}(t) \\
\overline{\Delta \theta}_{f 5}(t) \\
\overline{\Delta \theta}_{z 5}(t)
\end{array}\right] \\
& \mathbf{u}(t)=\left[\begin{array}{l}
\overline{\Delta \theta}_{f}^{u}(t) \\
\overline{\Delta \theta}_{g}^{u}(t)
\end{array}\right]=\left[\begin{array}{l}
u_{1}(t) \\
u_{2}(t)
\end{array}\right] \\
& x_{i}(t)=\overline{\Delta \theta}_{f, 5}(t)=\overline{\Delta \theta}_{f, 5}^{\text {out }}(t)
\end{aligned}
$$$$
A=\left(\begin{array}{ccccc}
A_{1}^{2} & 0 & 0 & 0 & 0 \\
A_{2}^{1} & A_{2}^{2} & 0 & 0 & 0 \\
0 & A_{3}^{1} & A_{3}^{2} & 0 & 0 \\
0 & 0 & A_{4}^{1} & A_{4}^{2} & 0 \\
0 & 0 & 0 & A_{5}^{1} & A_{5}^{2}
\end{array}\right), \quad B=\left(\begin{array}{c}
B_{1} \\
B_{2} \\
B_{3} \\
B_{4} \\
B_{5}
\end{array}\right)
$$$$
\mathbf{c}^{T}=\left[\begin{array}{llllllllll}
0 & 0 & 0 & 0 & 0 & 0 & 0 & 0 & 1 & 0
\end{array}\right]
$$

Matrices $A_{k}^{1}, A_{k}^{2}$ i $B_{k}, k=1,2,3,4,5$ are given, in details, in [03].

It is known [06] that output controllability conditions for the process, given eq. (16), can be expressed in the following form:

$$
\begin{gathered}
U=\left(\begin{array}{ccccc}
\mathrm{c} B & \mathrm{c} A B & \mathrm{c} A^{2} B & \ldots & \mathrm{c} A^{n-1} B
\end{array}\right) \\
n=1,2, \ldots, 10
\end{gathered}
$$

In the present case it can be shown that:

$\operatorname{rank} U=\operatorname{rank}\left(\mathrm{c} B \quad \mathrm{c} A B \quad \mathrm{c} A B \quad \cdots \quad \mathrm{c} A^{n-1} B\right)=1$

indicating that the output of the process (plant) is controllable.

The condition number of $U, \wp_{U}(A, B, C)$, is used as an indicator of the degree to which the process may be controlled with a bounded input [07].

The condition number of matrix $U$ can be expressed as ratio of the largest to smallest singular values of $U$ :

$$
\wp_{U}(A, B, C)=\frac{\sigma_{\max }(U)}{\sigma_{\min }(U)}, \quad U=U(A, B, C)
$$

where $\sigma_{\max }\{\}, \sigma_{\min }\{\}$ are maximum and minimum singular values of $U$.

If the controllability matrix $U$ is singular and not of full rank the condition number $\wp_{U}(A, B, C)$ is infinite.

Also at the minimum $\wp_{U}(A, B, C)$ the process is most controllable.

Thus the condition number will provide the information on the best situation for control of the cross-flow heat exchanger.

The cross-flow heat exchanger has a three dimensional parameters that can be varied: inner diameter $d_{i}$, outer diameter $d_{0}$ and the length $L$ which result in a three geometric degree of freedom.

In order to reduce this degree of freedom, two geometric constraints will be taken into account, the total volume and the mass of the heat exchanger. form:

The total volume can be expressed in the following

$$
V=\frac{\pi d_{0}}{4} L
$$

The volume of the heat exchanger constraint can be reperesented by the volume occupied by the solid part of the tube:

$$
V_{t}=\frac{\left(d_{0}^{2}-d_{i}^{2}\right) \pi}{4} L
$$

A non-dimensional parameter can be used to represent the ratio of the tube volume to the total volume:

$$
\varphi=\frac{V_{t}}{V}=1-\frac{d_{i}^{2}}{d_{0}^{2}}
$$


These two constraints will decrease the number of geometric degree of freedom to one, that will be presented by the dimensionless aspect ratio $\frac{d_{0}}{L}$.

The optimization process starts by numerically simulate the cross-flow heat exchanger and minimize its controllability matrix condition number $\wp_{U}(A, B, C)$ by varying its aspect ratio $\frac{d_{0}}{L}$ while keeping all other parameters constant as shown in Figure 8 .

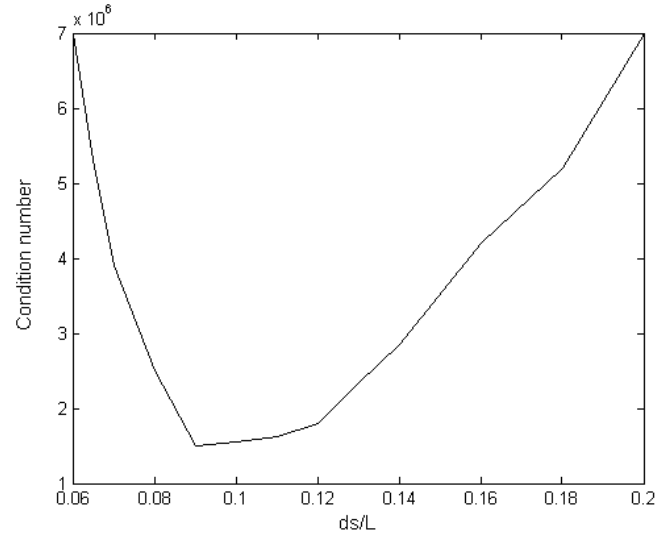

Figure 8 - Condition number vs. ratio $\frac{d_{0}}{L}$

In this figure it can be seen that there is a minimum $\wp_{U}$ with respect to the $\frac{d_{0}}{L}$ which means that the process is best controllable at this aspect ratio.

There are two extreme cases that is hard to control, when the aspect ratio $\frac{d_{0}}{L}$ is large and when it is small.

In both cases the condition number values are increasing.

This procedure ilustrated in Figure 8 has been repeated for different values of the fluid flow rate $G_{f N}$.

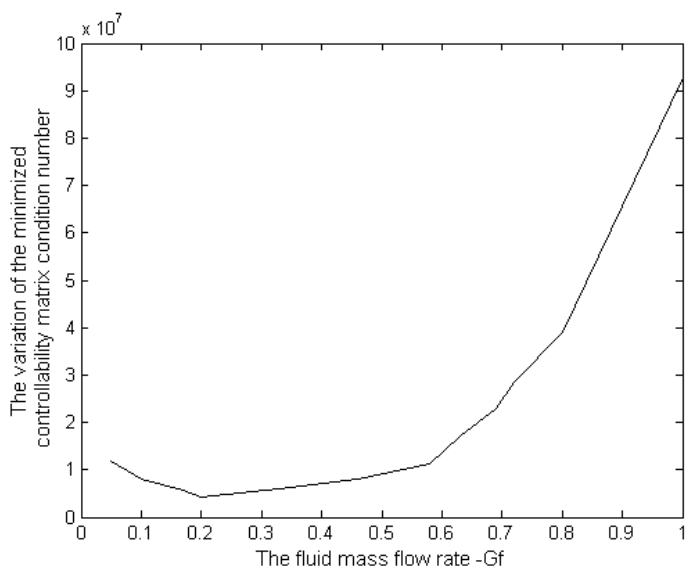

Figure 9.a - The minimum condition number $v s . G_{f N}$
The minimum condition number in each case labled $\wp_{U_{\min }}$ is drawn against $G_{f N}$ as shown in Figure 9

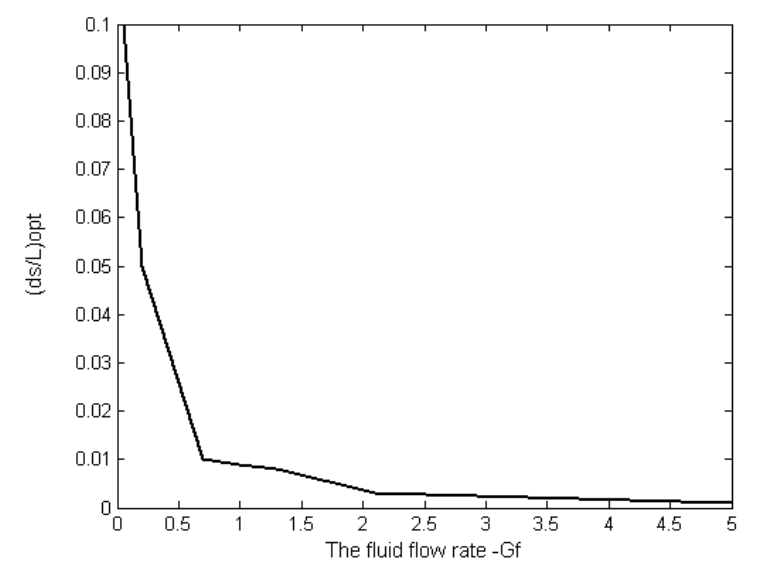

Figure 9.b - The optimal ratio $\frac{d_{0}}{L}$ vs. $G_{f N}$

It is clear that the already minimized $\wp_{U_{\min }}$ has a minimum value with respect to $G_{f N}$ which is mathematically expressed as:

$$
\frac{\partial^{2}}{\partial\left(d_{0} / L\right)}\left(\wp_{U}\right)=0
$$

Analyzing results, Fig. 9 it can be concluded that there are two extreme cases: a case of high fluid mass flow rate and a case of low fluid mass flow rate.

Both of this cases are hard to control which is well ilustrated in increasing of the minimized condition number.

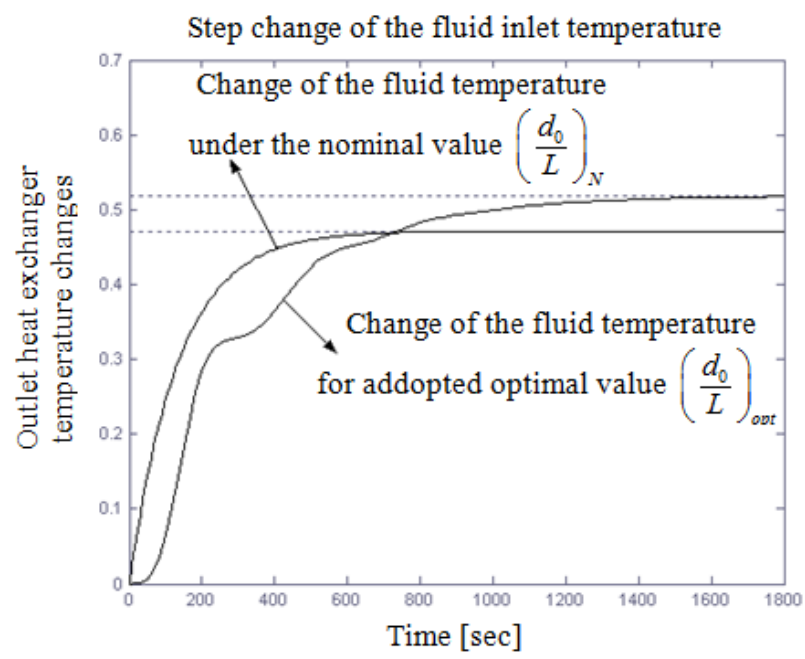

Figure 10 - Outlet heat exchanger temperature changes with respect to step change of the fluid inlet temperature,under the nominal value $\left(\frac{d_{0}}{L}\right)_{N}$ and for addopted optimal value $\left(\frac{d_{0}}{L}\right)_{\text {opt }}$ 
Some step respones, in the case of optimal conditional nuber, are given on Figure 10 and Figure 11.

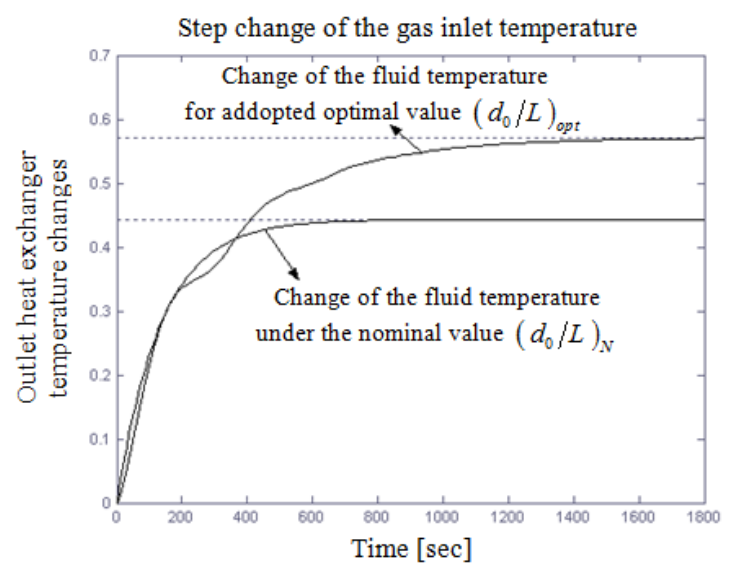

Figure 11 - Outlet heat exchanger temperature changes with respect to step change of the gas inlet temperature, under the nominal value $\left(\frac{d_{0}}{L}\right)_{N}$ and for addopted optimal value $\left(\frac{d_{0}}{L}\right)_{o p t}$

\section{CONCLUSION}

In this paper one characteristic method in mathematical modelling of the heat exchangers was considered.

Analyzing the analytical approach using Laplace transform it can be concluded that system of PDE is very complicated to be solved analytically and this model has only academical signification while its practical meaning is small.

One of the possible methods to avoid partial differential equations is the method of transport approach is based both on the spatial and time discretization which transforms the system of partial differential equations to the system of the algebric equations which can be solved using numerical, itterative procedures.

This procedure should be carried out taking into account the conditions for convergence of numerical procedures.

The aim of this work is also to study the ability of optimizing the geometry of heat exchangers with respect to its dynamic controllability which is quantified in the controllability matrix condition number using mathematical model of heat exchanger based on transport approach.

The controllability matrix condition number was minimized with respect to the tube aspect ratio and the fluid mass flow rate.

This procedure showed that optimizing the geometry of heat exchangers with respect to its controllability is important and should be taken into account in the design of the heat ehchangers.
This paper represent further extension of some previous results, given in [08] and [09].

Table 1. APENDIX A - Nomenclature

\begin{tabular}{|c|c|c|c|}
\hline & Parameter & Dimension & Value \\
\hline 1 & $c_{w}$ & $\mathrm{~kJ} / \mathrm{kgK}$ & 0,50 \\
\hline 2 & $\rho_{w}$ & $\mathrm{~kg} / \mathrm{m}^{3}$ & $8,12 \cdot 10^{3}$ \\
\hline 3 & $\lambda_{w}$ & $W / m K$ & $0,04 \cdot 10^{3}$ \\
\hline 4 & $r_{o}$ & $m$ & 0,015 \\
\hline 5 & $r_{i}$ & $m$ & 0,009 \\
\hline 6 & $w_{f}$ & $\mathrm{~m} / \mathrm{s}$ & 0,5 \\
\hline 7 & $G_{f}$ & $\mathrm{~kg} / \mathrm{s}$ & 0,12 \\
\hline 8 & $G_{a}$ & $\mathrm{~kg} / \mathrm{s}$ & 1,8 \\
\hline 9 & $\rho_{f}$ & $\mathrm{~kg} / \mathrm{m}^{3}$ & 952,38 \\
\hline 10. & $c_{f}$ & $\mathrm{~kJ} / \mathrm{kgK}$ & 4,233 \\
\hline 11. & $\alpha_{a w}$ & $W /\left(m^{2} K\right)$ & 220 \\
\hline 12. & $\rho_{a}$ & $\mathrm{~kg} / \mathrm{m}^{3}$ & 0,748 \\
\hline 13 & $\alpha_{w f}$ & $W /\left(m^{2} K\right)$ & 3800 \\
\hline 14. & $c_{a}$ & $\mathrm{~kJ} / \mathrm{kgK}$ & 1,097 \\
\hline 15. & $L$ & $m$ & 6 \\
\hline 16. & $\theta_{f N}^{i n}$ & ${ }^{\circ} \mathrm{C}$ & 110 \\
\hline 17. & $\theta_{a N}^{i n}$ & ${ }^{\circ} \mathrm{C}$ & 200 \\
\hline
\end{tabular}

\section{ACKNOWLEDGMENT}

This work has been supported by the Ministary of Science and Technological Department of Serbia under the Project ON 174001.

\section{REFERENCES}

[1] Romie F. E, Transient Response of the Counter-Flow Heat Exchanger, J. Heat Transfer 106 (3), 620-626, 1984.

[2] Roetzel W, Y Xuan, Transient/Response of Parallel and Counter-Flow Heat Exchangers, J. Heat Transfer, 114 (2), 510-512, 1992.

[3] Stevic Z. D, A Contribution to Comparative Dynamic Analysis and Geometric Optimization of Recuperative Heat Exchangers, Doctoral Dissertation, Belgrade, 2010.

[4] Ilic K, Dynamical behaviour of the heat ehchangers, M.Sc. Thesis, Faculty of Mechanical Engineering, Sarajevo, 1986. 
[5] Grujić Lj. T, Debeljković Lj. D, Differential Discrete Modelling and Controllability and Observability Analysis of Heat Exchangers, Technika, No 7-8, (1978).

[6] Klamka J, Controllability of Dynamical Systems, Kluwer Academic Publishers, Netherlands, 1991.

[7] Alotaibi S. M, Sen B. Goodwine, K. T. Yang, Controllability of Cross - Flow Heat Exchangers, International Journal of Heat and Mass Transfer, Vol. 47, 913-924, 2004.

[8] Simeunović G. V, Debeljkovic Lj. D, Stevic Z. D, "Dynamic properties and geometric optimization of double heat exchangers based on controlability condition number", Proc. $23^{\text {rd }}$ International Conference on Nuclear Engineering, Chiba-Tokyo (Japan) May 17 -21, (2015), Paper No. 1849 - ICONE 23.

[9] Stevic Z. D, Debeljkovic Lj. D, Simeunović V. G, Misić A. M, "Comperative analysis of different methods in mathematical modelling of the recuperative heat exchangers ", Proc. $23^{\text {rd }}$ International Conference on Nuclear Engineering, Chiba-Tokyo (Japan), May 17 - 21, Paper No. 1848 - ICONE 23, 2015.

\section{REZIME}

\section{MODELOVANJE, SIMULACIJA I GEOMETRIJSKA OPTIMIZACIJA JEDNOG REKUPERATIVNOG RAZMENJIVAČA TOPLOTE SA UNAKRSNIM STRUJANJEM RADNIH FLUIDA BAZIRANA NA USLOVNOM INDEKSU UPRAVLJIVOSTI}

Ovaj rad, u prvom redu, izvodi algebarski matematički model jednog razmenjivača toplote sa unakrsnim strujanjem radnih fluida, izveden na bazi primene tzv. "transportnog prilaza". Rad ovog razmenjivača, u prisustvu promenljivog opterećenja, obično se upravlja ili promenom ulazne temperature radnog fluida ili njegovim masenim protokom. Cilj ovog rada je da se postupkom optimizacije geometrije razmenjivača, iznađe optimalna ulazna vrednost protoka ulaznog nestišljivog radnog fluida ili ulazne vrednosti ulaznog protoka gasovitih produkata sagorevanja a sve to sa pozicija primene odgovarajućeg indeksa performansi, zasnovanog na osobinama upravljivosti razmatranog procesa.

Prema tome, uslovni indeks upravljivosti se koristi da pruži neophodne informacije za što kvalitetnije $i$ racionalnije upravljanje ovom klasom razmenjivača toplote. Ovaj koncept, s druge strane, može da pruži i informaciju o najjednostavnijim uslovima realizacije upravljanja da bi se postigao željeni cilj u smislu ponašanja određene uzlazne veličine razmenjivača toplote. Matematički model, koji izražava dinamičko ponašanje razmenjivaća toplote u njegovim prelaznim stanjima, iskorišćen je za dobijanje numeričkih rešenja koja iskazuju nestacionarne pojave.

Izvršena je optimizacija uslovnog indeksa upravljivosti, koji je inače iskazan kroz geometrijske parametre zidova cevi razmenjivača toplote, $i$ to u prisustvu zapreminskih ograničenja, a namenski za optimalne operacije vezane za postizanje željene izlazne upravljivosti. Korišćeni uslovni indeks upravljivosti, iskazan kao količnik geometrijskih parametara zidova cevi, masenog protoka primarnog fluida i izlazne upravljivosti, proučavan je i analiziran je u odnosu na bazične karateristike cevi.

Ključne reči: razmenjivač toplote sa unakrsnim strujanjem radnih fluida, transportni prilaz, prelazni radni režimi, uslovni indeks upravljivosti 